\title{
Influence of Information Communication and Technology Strategies on Organization Performance in the Airline Industry: A Case of Kenya Airways Limited
}

\author{
Wahu Salome Gathoni \& Dr Assumptah Kagiri \\ Department of Entrepreneurship, Procurement \& Management, Jomo Kenyatta University of Agriculture \& \\ Technology P.O. BOX 62000-00200 Nairobi, Kenya, Wahu Salome Gathoni P.O. Box 15906-00100 GPO \\ Nairobi.
}

\begin{abstract}
Organisational performance of an organization defines the organizations continuity. A firm's sustainability is highly dependent on its strategies to improve and advance operations. Corporate success in todays' market environment is defined by some factors which are out of the direct control of an organization, yet organizations have to adapt to the external environments dynamic ways for their survival. There are ICT networks to deliver a wide range of value added products and services to customers in the airline industry. The airline business depends on the wellbeing of international trade and the stability of the markets. The general objective of this study was to determine the influence of Information Communication and Technology strategies on the organizational performance of Kenya Airways Limited. In doing this the study seeked to determine the influence of computerized reservation systems, internet applications, communication networks and systems integration on the organizational performance of Kenya Airways Limited. The study concluded that all the four independent variables influence performance of the organization. Computerized reservation systems, internet applications, communication networks and systems integration positively influence the performance of Kenya Airways. Despite the fact that the profitability of Kenya Airways has gone down over the years, systems of the operations have improved overtime and approved internally.
\end{abstract}

Keywords: Computerized Reservation System, Internet Applications, Communication Networks, Communication Networks, Information Systems Integration, Organizational Performance

\section{INTRODUCTION}

Airlines in the world continue to make strategic choices in order to improve on their product offer, enhance better service delivery, reduce on overall costs and cope with industry competition and challenges (Kamau, 2015). Airlines are under unprecedented pressure to produce sustainable economic results or perish as fuel, labor and asset cost escalates and demand declines. With the industry positioned for recovery from time to time, competition is expected to intensify as low-cost carriers continue to gain market share from full-service carriers by attracting both leisure and business segments. In addition, new operating model, innovative entrants and further airline consolidation will create more difficulties and intense competition. Financial performance of an organization defines the organizations continuity. A firm's sustainability is highly dependent on its management of finances. Corporate success in today's market environment is defined by some factors which are out of the direct control of an organization, yet organizations have to adapt to the external environments dynamic ways for their survival. The effect of external environmental factors on the financial performance of the airline industry especially in Kenya has received little attention in academic inquiry. The airline business depends on the wellbeing of international trade and the stability of the markets. According to Kariuki (2015), Information Technology (IT) is clearly considered as a key growth area in this century due to the dynamic and highly competitive business environment which requires utilizing advanced IT tools to improve efficiency, cost effectiveness, and deliver high quality products and services to customers.

IT is also considered as a tool of marketing, contacting customers and looking for possible customers, as well as presenting IT services as distinguished potential services for customers. Kenya Airways issues its staff with mobile phone and current technological hand held devices such as iPads for official as a way of integrating ICT to business to boost performance of the airline. Mobile phone usage in Kenya Airways is governed by the Telephone Policy which documents all telephone usage in Kenya Airways such as landlines, calling codes amongst other communication facilities. In order to appeal to prospective shareholders, KQ has to become more efficient and competitive. The Airlines' profitability is closely tied to economic growth and trade. $\mathrm{KQ}$ has to recognize the need for radical change to ensure its survival and prosperity as the future holds many challenges and effective strategic choices have to be made to successfully continue to tackle high costs and 
improve their products. In order to appeal to prospective shareholders, KQ has to become more efficient and competitive. The Airlines' profitability is closely tied to economic growth and trade.

\section{STATEMENT OF THE PROBLEM}

Airline profits continue to be throttled down by the global economic downturn, high fuel costs and the prospect of ever more stringent environmental regulations. In order to survive and prosper in these conditions, airlines must rationalize their processes and increase asset utilization to a greater degree than ever before. This will require business-driven IT transformation which is the fundamental redesign and integration of business systems and processes within and across airline functions, (Wanguku, 2012). Airlines will have to carefully manage the internal demand for IT services, implement project delivery methodologies that focus on business process design and change management. Those that do so will be able to significantly raise their business performance and earn improved returns on their IT investments. Financial performance is conceptualized as the extent to which a firm increases sales, profits and return on assets. These are the indicators of financial performance and manifest the wellbeing of a firm collectively. Recent statistics suggest that Kenya Airways market dominance and profitability has not only been declining over the past few years, it has been performing poorly in its market 6 share in terms of international flights from Kenya compared to foreign airlines. Growing competition in Kenya's airline industry has increasingly put pressure on Kenya Airways market share and passenger yields; factors which require the company to implement appropriate strategies to enhance growth and profitability. Through the e-commerce platform, Airlines enhance their relationship with their passengers who will book directly with the airline rather than through travel agents. E-commerce enables airlines to offer more services to customers, more channels to deliver their business, more intelligence to understand their business, greater efficiency and lower cost. The financial performance trends indicate that the financial performance of KQ has deteriorated over the years despite increase in sales (Ochieng, 2015).

\section{LITERATURE REVIEW}

The general objective of this study was to determine the influence of Information Communication and Technology strategies on the organizational performance of Kenya Airways Limited. While the specific objectives are to determine the influence of computerized reservation systems, internet applications, communication networks and systems integration on the organizational performance of Kenya Airways Limited. This study made use of three theories related to the independent and dependent variable of this study. These theories include Resource Based theory, Technological, Organizational and Environmental Model and Open System Theory.

\section{Resource Based Theory}

Edith Penrose's contributed to the resource based view as early as 1959 when she argued that a firm is more than an administrative unit, it is also a collection of productive resources on the disposal will be different users and over time is determined by administrative decision. She came to the conclusion that the existing theory of the firm was inadequate to explain how firms grow. The competitive advantage in the firm lies primarily in the application of a bundle of valuable tangible or intangible resources at the firm's disposal, (Penrose, 1959). The theory suggests that competitive advantage and performance results are a consequence of firm-specific resources and capabilities that are costly to copy by other competitors, (Barney, 1986). These resources and capabilities can be important factors of sustainable competitive advantage and superior firm performance if they possess certain special characteristics. They should be valuable, increasing efficiency and effectiveness, rare, imperfectly imitable and non-substitutable, (Barney, 1991). These resources if protected by firms can earn sustainable supernormal returns if and only if they have superior resources by some form of isolating mechanisms diffused on throughout the industry. Therefore the theory emphasizes strategic choice changing the firms' management with the important task of identifying, developing and deploying key resources to maximize returns.

\section{Technological, Organizational and Environmental Model}

Realizing the importance of technology adoption, Tornatzky et al., (1990), developed the Technological Organisational and Environmental (TOE) model to evaluate technology adoption. The model identifies three aspects of firm's characteristics that influence the process of adopting, implementing and using technological innovations. First technological context describes both existing and new technologies relevant to the firm such as prior technology usage and number of computers in the firm which determines the ability of the firm to move to e-commerce and other technology initiatives. Secondly, organizational context refers to descriptive measures related to organizations such as firm scope, firm size and managerial beliefs. Thirdly, environmental context focuses on areas which the firm conducts its business operations, with the priority given to external factors influencing the industry that have significant impacts on the firm such as government incentives, ICT and regulations. 


\section{Open System Theory}

Open system theory was developed by Bertanlanffy (1956). Open systems theory refers simply to the concept that organization performance is strongly influenced by their environment. The environment consists of other organizations that exert various forces of an economic, political, or social nature. The environment also provides key resources that sustain the organization and lead to change and survival. Organizations and communities conduct their business in a way they influence and change their external environments, while at the same time being influenced by external changes in local and global environments. This two-way influential change is known as active adaptive change. Organisations are considered as open system as they influence each other over time. Through their actions they influence and change their external environment, and at the same time are constantly being influenced by changes in the external environment. The Airline industry in Kenya is considered to be an open system because its competitiveness is significantly affected by the international environmental factors that eventually affect its performance.

\subsection{Conceptual Framework}

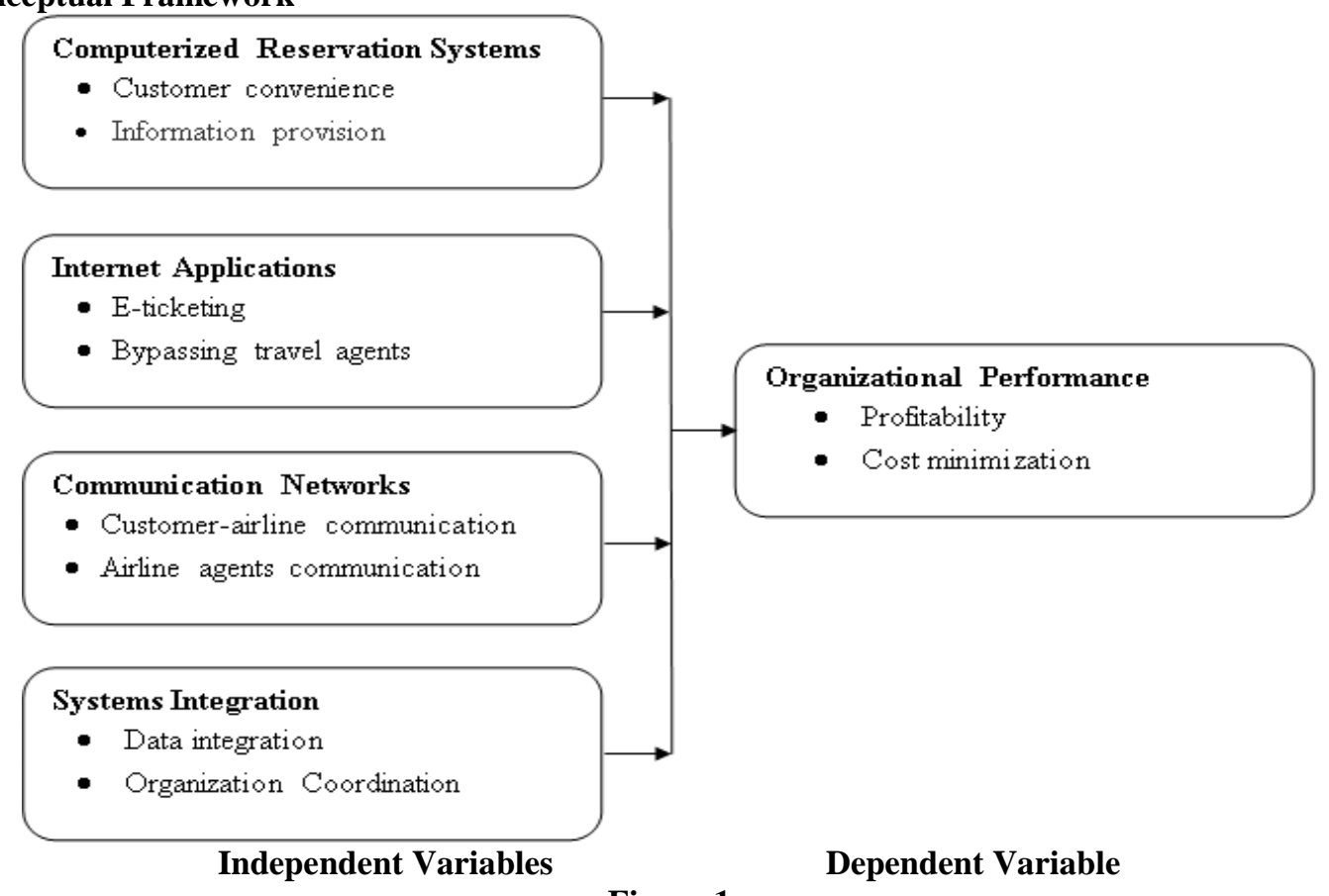

Figure 1

Computerized Reservations Systems technology has created more than just enhanced technical efficiency for travel agents and airlines. Also airlines exploit the system as a competitive weapon, (Copeland $e t$ al., 2010). Airlines have installed computerized reservations systems in travel agencies to appropriate the returns from their investments in information technology. The airlines are expected to obtain a number of benefits from this strategy, including increased efficiency, possible bias in favor of the computerized reservations systems owner on the part of the travel agent and fees from other airlines for making reservations for them. The results of both analyses support hypotheses that computerized reservations systems ownership is positively related to airline performance. Airlines identified the Internet as a major opportunity to tackle distribution costs and to reengineer the structure of the industry. Fogli et al., (2014), assert that suitable extranets and inter-organizational systems are required to facilitate airline interaction with their regular suppliers. Airlines are customers of airports, air control systems, and other authorities such as immigration and customs. Airlines, therefore, regularly exchange information with airport authorities and air traffic control systems, (Verlinda et al., 2013). These flows include requests for landing slots and docking gates, informing about arrivals and departures, altering slots, declaring flight paths, and coordinating operations.

Communication networks are the patterns of contact that are created by the flow of messages among communicators through time and space, (Coombs, 2013). Airlines have bases and distributors around the world, particularly at destinations they serve. Hence, they need efficient co-ordination and communications with stations, branches, distributors, and customers globally. Interaction with distributors, travel agencies, and other distributors can determine levels of sales whilst efficient invoicing and revenue collection is critical for both cash flow and profitability, (Cooper, 2016). The aim of information systems integration is to maximize business performance, productivity and improvement. This in turn is hoped to drive organizational effectiveness and 
competitiveness in the marketplace. The most common form of information systems integration need is data integration. Profit is the ultimate goal of the airline firms. All the strategies designed and activities performed thereof are meant to realize this grand objective. Measuring performance is a multi-dimensional concept.

\section{RESEARCH METHODOLOGY}

This study used a descriptive research as it involves gathering of information on the prevailing situation for the purpose of description and interpretation. The major purpose of descriptive research is description of the state of affairs as it exists at present (Kothari, 2009). A population consists of all items in any field of inquiry. The target population of this study was all the employees of Kenya Airways Limited. According to Kenya Airways Limited (2016), the company has 3,986 employees. The study used stratified random sampling to select 98 employees from the target population. In this technique, a population is stratified first into senior management, middle management and operational staff; then random sampling is done. This study used of both primary and secondary data. The pilot test was conducted with a randomly selected number staff at Wilson Airport. The pilot group comprised of $10 \%$ of the sample size. The Cronbanch's Alpha technique was used to measure the internal consistency technique, where alpha values range from 0 to 1 , with the reliability increasing as the alpha value increases. The commonly used coefficient of reliability is 0.6 to 0.7 , with greater than or equal to 0.8 indicating a good reliability, (Kothari, 2009). In this study, a Cronbanch's Alpha of 0.7 and above was accepted. The semi structured questionnaire generated both qualitative and quantitative data, which was analyzed differently using different methods.

\section{Research Findings}

Out of the of 98 questionnaires respondents that were administered to the interviewees, 89 of them were returned for analysis. This translates to a response rate of $90.8 \%$. Some of the respondents could not be reached due to their tight schedules and frequent meetings; an effort to reach them through the contact person established was not successful.

Table 1: Response rate

\begin{tabular}{|l|l|l|}
\hline Response Rate & Frequency & Percent \\
\hline Questionnaires issued & 98 & 100.0 \\
\hline Questionnaires returned & 89 & 90.8 \\
\hline Questionnaires not returned & 9 & 9.2 \\
\hline
\end{tabular}

The data was then analysed using descriptive and inferential statistical measures as follows:

\subsection{Demographic Characteristics of Respondents}

The researcher requested the respondents to fill out their gender to ensure fair distribution of questionnaires to the male and female working in Kenya Airways. From the data, 56.2\% of the respondents were male while $43.8 \%$ of the respondents were female.

Table2: Distribution of the respondents by gender

\begin{tabular}{|l|l|l|}
\hline Gender & Frequency & Percent \\
\hline Female & 39 & 43.8 \\
\hline Male & 50 & 56.2 \\
\hline Total & $\mathbf{8 9}$ & $\mathbf{1 0 0 . 0}$ \\
\hline
\end{tabular}

To know which age bracket are the majortiy in Kenya Airways, the respondents were asked their age, this is for general information and is not a direct objective of the study. The highest percent of the respondents were between the age brackets of 36-40 years represented by $27 \%$. The rest of the findings are presented on table 3 below.

Table 3: Distribution of respondents by age

\begin{tabular}{|l|l|l|}
\hline Age & Frequency & Percent \\
\hline Below 25 years & 9 & 10.1 \\
\hline 26-30 years & 18 & 20.2 \\
\hline 31-35 years & 20 & 22.5 \\
\hline 36-40 years & 24 & 27.0 \\
\hline 41-45 years & 14 & 15.7 \\
\hline 0ver 46 years & 4 & 4.5 \\
\hline Total & $\mathbf{8 9}$ & $\mathbf{1 0 0 . 0}$ \\
\hline
\end{tabular}


Out of the 89 respondents $42.7 \%$ of the respondents had attained education to the diploma level, $18 \%$ degree level, $32.6 \%$ to the masters level, $6.7 \%$ to the $\mathrm{PhD}$ level. The data as displayed on the table 4 below depict Kenya Airways employs well learned professionals who have attained tertiary level of education.

Table 4: Distribution of the respondent by education level

\begin{tabular}{|l|l|l|}
\hline Level of Education & Frequency & Percent \\
\hline Diploma & 38 & 42.7 \\
\hline Degree & 16 & 18.0 \\
\hline Masters & 29 & 32.6 \\
\hline PhD & 6 & 6.7 \\
\hline Total & $\mathbf{8 9}$ & $\mathbf{1 0 0 . 0}$ \\
\hline
\end{tabular}

The study further sought to find out the respondent's department orientation. This question was asked to understand the distribution of the work departments of the respondents to show the extent of the use of ICT across the organisation. From table 5 below, $15.7 \%$ of the respondents were from Audit department, $15.7 \%$ Commercial, 12.4\% Finance, 15.7\% Information Systems (IS), 10.1\% Marketing, 12.4\% Operation Control and $18 \%$ technical department.

Table 5: Distribution of the respondents by department

\begin{tabular}{|l|l|l|}
\hline Department & Frequency & Percent \\
\hline Audit & 14 & 15.7 \\
\hline Commercial & 14 & 15.7 \\
\hline Finance & 11 & 12.4 \\
\hline Information Systems & 14 & 15.7 \\
\hline Marketing & 9 & 10.1 \\
\hline Operation Control & 11 & 12.4 \\
\hline Technical & 16 & 18.0 \\
\hline Total & $\mathbf{8 9}$ & $\mathbf{1 0 0 . 0}$ \\
\hline
\end{tabular}

The respondents were asked on the number of years worked so as to assess the level of experience and knowledge of information regarding the organization. Most of the respondents were observed to have worked in KQ for less than 10 years represented by $67.4 \%$. This was followed by respondents who have worked in KQ between 11-20 years at $14.6 \%$ while those above 25 years are $7.8 \%$. This means that all the respondents had a wide range of experience in Kenya Airways and the company retains employees and is probably a good employer.

Table 6: Distribution of the respondents by duration of service

\begin{tabular}{|l|l|l|}
\hline Duration of service & Frequency & Percent \\
\hline less than 5years & 31 & 34.8 \\
\hline 6-10 years & 29 & 32.6 \\
\hline 11-15 years & 9 & 10.1 \\
\hline 16-20 years & 4 & 4.5 \\
\hline 20-25 years & 9 & 10.1 \\
\hline 25-30 years & 1 & 1.1 \\
\hline Above 30 years & 6 & 6.7 \\
\hline Total & $\mathbf{8 9}$ & $\mathbf{1 0 0}$ \\
\hline
\end{tabular}

\subsection{Descriptive statistics}

All the respondents (100.0\%) agreed that Kenya Airways has adopted Computerised Reservation Systems to great extent. And that this adoption has improved the performance of the airline. The study observed that adoption of computerized reservation system influence organization performance to a great extent represented by a mean of 1.8876 and standard deviation of 0.78968 as per the Table 7 below.Direct contact with the passenger influence organization performance to a great extent as represented by a mean of 1.9663 and standard deviation of 0.8041 . Computerized reservation systems influence customer convenience to a great extent. Reservation services influence organization performance to a great extent as represented by a mean of 1.9101 and standard deviation of 0.76337 . Finally the information provision influence organization performance to a moderate extent as represented by a mean of 2.0 and a standard deviation of 0.65088 . The respondents commented that the computerized reservation have had addition benefits like reduction of customer complaints and savings on human resources. 
Table 7: Computerized Reservation Systems on Organization Performance

\begin{tabular}{|l|l|l|}
\hline Statement & Mean & Std. Deviation \\
\hline $\begin{array}{l}\text { To what extent does the adoption of computerized reservation system influence the performance of } \\
\text { Kenya Airways Limited? }\end{array}$ & 1.8876 & .78968 \\
\hline $\begin{array}{l}\text { To what extent does the Direct contact with the passenger influence organizational performance in } \\
\text { Kenya Airways Limited? }\end{array}$ & 1.9663 & .80410 \\
\hline $\begin{array}{l}\text { To what extent does the computerized reservation systems influence Customer convenience in } \\
\text { Kenya Airways Limited? }\end{array}$ & 1.9432 & .76351 \\
\hline $\begin{array}{l}\text { To what extent does the Reservation services systems influence organizational performance in } \\
\text { Kenya Airways Limited? }\end{array}$ & 1.9101 & .76337 \\
\hline $\begin{array}{l}\text { To what extent does the Information provision influence organizational performance in Kenya } \\
\text { Airways Limited? }\end{array}$ & 2.0899 & .65088 \\
\hline
\end{tabular}

The respondents agreed that E-ticketing influence organizational performance to a great extent as represented by a mean of 2.2921 and standard deviation of 0.5477. By-passing travel agents and transparent and clear pricing influence organizational performance to a moderate extent as represented by a mean of 2.2809 and 2.3483. Online and advertising influence organizational performance to a moderate extent as presented by a mean of 2.2809 and standard deviation of 0.58366 on Table 8 below.

Table 8: Internet Applications on Organization Performance

\begin{tabular}{|l|l|l|}
\hline Statement & Mean & Std. Deviation \\
\hline $\begin{array}{l}\text { To what extent does E-ticketing influence organizational performance in Kenya Airways } \\
\text { Limited? }\end{array}$ & 2.0000 & .72300 \\
\hline $\begin{array}{l}\text { To what extent does By-passing travel agents influence organizational performance in Kenya } \\
\text { Airways Limited? }\end{array}$ & 2.2809 & .52199 \\
\hline $\begin{array}{l}\text { To what extent does Transparent and clear pricing influence organizational performance in } \\
\text { Kenya Airways Limited? }\end{array}$ & 2.3483 & .65888 \\
\hline $\begin{array}{l}\text { To what extent does Online promotions and advertising influence organizational performance } \\
\text { in Kenya Airways Limited? }\end{array}$ & 2.2809 & .58366 \\
\hline
\end{tabular}

The respondents were asked to comment on how communication network has influenced the organization performance. The respondents agree to a great extent that the communication network influence the performance of Kenya Airways as shown by a mean of 1.7753 and standard deviation of 0.79419 . The respondents also agree to a great extent the Customer-airline communication, Crew-airline communication and Maintenance-crew communication influence the performance of Kenya Airways; this is represented by a mean of $1.7753,1.7416$ and 1.7865 respectively. Suppliers-airline communication and inter-organizational communication influence the performance of Kenya Airways, as represented on table 9 with a mean of 1.7753 and 1.9551 respectively. The respondents also commented that communication with suppliers had improved over time and this had led to a positive relationship between Suppliers and the airline.

Table 9: Communication Network on Organization performance

\begin{tabular}{|c|c|c|}
\hline Statement & Mean & $\begin{array}{l}\text { Std. } \\
\text { Deviation }\end{array}$ \\
\hline $\begin{array}{l}\text { To what extent does communication network influence the organizational performance in Kenya } \\
\text { Airways Limited }\end{array}$ & 1.7753 & .79419 \\
\hline $\begin{array}{l}\text { To what extent does Customer-airline communication influence organizational performance in } \\
\text { Kenya Airways Limited? }\end{array}$ & 1.7753 & .79419 \\
\hline $\begin{array}{l}\text { To what extent does Crew-airline communication influence organizational performance in } \\
\text { Kenya Airways Limited? }\end{array}$ & 1.7416 & .76170 \\
\hline $\begin{array}{l}\text { To what extent does Maintenance-crew communication influence organizational performance in } \\
\text { Kenya Airways Limited? }\end{array}$ & 1.7865 & .80442 \\
\hline $\begin{array}{l}\text { To what extent does Suppliers-airline communication influence organizational performance in } \\
\text { Kenya Airways Limited? }\end{array}$ & 1.7753 & .76504 \\
\hline $\begin{array}{l}\text { To what extent does Inter-organizational communication influence organizational performance } \\
\text { in Kenya Airways Limited? }\end{array}$ & 1.9551 & .75242 \\
\hline
\end{tabular}

The respondents agreed to a great extent that strategic system integration influence the performance of your organization represented by a mean of 1.7191 and 0.82557 on Table 10 below. Data integration between departments, Information sharing, Organization Coordination influences organization performance to a great extent represented by a mean of $1.7753,1.7528$ and 1.7303 respectively. Integration with suppliers influence organizational performance in Kenya Airways Limited to a great extent as represented by a mean of 1.7753 and standard deviation of 0.80838 . 
Table 10: System integration on Organization performance

\begin{tabular}{|l|l|l|}
\hline Statement & Mean & Std. Deviation \\
\hline $\begin{array}{l}\text { To what extent does strategic system integration influence the performance of your } \\
\text { organization? }\end{array}$ & 1.7191 & .82557 \\
\hline $\begin{array}{l}\text { To what extent does Data integration between departments influence organizational } \\
\text { performance in Kenya Airways Limited? }\end{array}$ & 1.7753 & .83602 \\
\hline $\begin{array}{l}\text { To what extent does Information sharing influence organizational performance in Kenya } \\
\text { Airways Limited? }\end{array}$ & 1.7528 & .81577 \\
\hline $\begin{array}{l}\text { To what extent does Organization Coordination influence organizational performance in Kenya } \\
\text { Airways Limited? }\end{array}$ & 1.7303 & .79436 \\
\hline $\begin{array}{l}\text { To what extent does the Integration with suppliers influence organizational performance in } \\
\text { Kenya Airways Limited? }\end{array}$ & 1.7753 & .80838 \\
\hline
\end{tabular}

The respondents agreed that rate of improvement in service delivery have improved to a moderate extent. Customer satisfaction, efficiency in service delivery and cost minimisation influence performance of the Kenya Airways to a moderate extent as represented by a mean of $2.2921,2.2022$ and 2.3371 respectively on Table 11 below.

Table 11: Organization performance of Kenya Airways

\begin{tabular}{|l|l|l|}
\hline Statement & Mean & Std. Deviation \\
\hline How do you rate improvement in service delivery in Kenya Airways currently? & 2.3146 & .57595 \\
\hline To what extent does Customer satisfaction influence the performance in Kenya Airways? & 2.2921 & .54777 \\
\hline To what extent does Efficiency in service delivery influence performance in Kenya Airways? & 2.2022 & .54730 \\
\hline To what extent does Cost minimization influence the performance in Kenya Airways? & 2.3371 & .62055 \\
\hline
\end{tabular}

\subsection{Regression analysis}

$\mathrm{p}<0.05$, dependent variable; computerized reservation systems, internet applications, communication networks and systems integration. From the table 12 below the coefficients of the regression are used to come up with the following regression equation:

$\mathrm{Y}=0.417+0.737 \mathrm{X}_{1}+0.695 \mathrm{X}_{2}+0.196 \mathrm{X}_{3}+0.480 \mathrm{X}_{4}$

Where $\mathrm{X}_{1}, \mathrm{X}_{2}, \mathrm{X}_{3}$ and $\mathrm{X}_{4}$ are computerized reservation systems, internet applications, communication networks and systems integration respectively. The study established that taking all the factors being constant at zero, the organization performance is 0.417 . The findings presented also show that holding all other independent variables at zero, a unit increase in computerized reservation systems would lead to 0.737 growth in organization performance, a unit increase in internet applications would lead to 0.695 in organization performance. A unit increase in communication networks would lead to 0.196 growth in organization performance, a unit increase in system integration would lead to 0.48 in organization performance.

Table 12: Regression Coefficients

\begin{tabular}{|l|l|l|l|l|l|l|}
\hline Model & & \multicolumn{2}{|l|}{$\begin{array}{l}\text { Unstandardized } \\
\text { Coefficients }\end{array}$} & $\begin{array}{l}\text { Standardized } \\
\text { Coefficients }\end{array}$ & T & Sig. \\
\hline \multirow{3}{*}{1} & & B & Std. Error & Beta & & \\
\cline { 2 - 8 } & Constant & .417 & .984 & & 1.101 & .017 \\
\cline { 2 - 8 } & Computerized Reservation System & .737 & .537 & .334 & 2.679 & .006 \\
\cline { 2 - 8 } & Internet applications & .695 & .441 & .029 & 3.093 & .027 \\
\cline { 2 - 8 } & Communication Networks & .196 & .695 & .065 & 2.758 & .048 \\
\cline { 2 - 8 } & Systems Integration & .480 & .258 & .681 & 3.247 & .018 \\
\hline
\end{tabular}

These results imply that increase in computerized reservation would lead to positive growth of the organization performance. An increase in internet applications would lead to a positive growth in organization performance. An increase in communication networks would also lead to positive growth in the organizational performance and finally system integration would lead to positive growth in organizational performance. Computerised reservation has the highest influence on the organizational performance, followed by internet applications as represented by 0.695 , followed by system integration as represented by 0.48 and finally communication network as represented by 0.196 . All the four variables were noted to have a positive influence on the organizational performance.

\subsection{Findings}

The study concluded that computerized reservation system influence performance of the organization positively. This is to the fact that there is direct contact with the passenger and information provision at any given time. This makes it convenience and fast for the customers to transact. Computerized reservation systems influence customer convenience creating a customer loyalty. Internet applications positively 
influence the performance of the organization. Some of the services include E-ticketing where the customers book and check-in flights online. The internet applications also help in communications between various departments, suppliers and customers. Transparency and clear pricing positively influence the performance of Kenya Airways; customers prefer pricing without hidden charges for their planning purposes. Communication networks have influenced the performance of Kenya Airways. Some of the efficiencies enhanced are customerairline, crew-airline, maintenance-crew, Supplier-airline communications enhancing relationship. Kenya Airways have also benchmarked with some of the international organizations to meet the international standards thus making the airline the pride of Africa. Communication networks have enhanced communications between parties involved in Kenya Airways which have led to faster resolution of complaints. The organization is able to communicate with customers either through emails or phone calls and inform them on any changes in flight to avoid customer frustrations. The departments involved in operations control are able to communicate with the crew for effective and efficient operations. Strategic system integration, data integration between departments, information sharing, organization coordination and integration with suppliers have influenced the performance of Kenya Airways. The airline uses a system that is integrated with customers and suppliers creating efficiency in most of the services. System integration has enhanced operations in Kenya airways because data is availed in the company portal.

\section{CONCLUSION}

The study concluded that all the four independent variables influence performance of the organization. Computerized reservation systems, internet applications, communication networks and systems integration positively influence the performance of Kenya Airways. Despite the fact that the profitability of Kenya Airways has gone down over the years, systems of the operations have improved overtime and approved internally. This agrees with a study by Ochieng (2015), which revealed that Kenya Airways financial performance is greatly influenced by the external environmental factors that include political factors such as regulations and restrictions related to international trade and tax policy, economical environmental factors, social factors that set preferences and taste in line with demographic factors like age, Technological factors that include paperless ticketing, customer friendly internet interface that allows for real time online booking, ticketing and checking in, environmental and legal factors like trade policies when entering new markets. Computerized reservation systems and internet applications were found to have a very strong positive influence on the organizational performance. Other areas of improvement contributed by information technology was the airline safety, convenient schedule, reputation of the airline previous flight experience, punctuality, ticket price and flight availability.

The management should enhance the systems used in reservations by ensuring that there are no downtimes. The study recommends to the management of Kenya Airways to make provision of ICT applications and infrastructure at all times to ensure customer satisfaction, efficiency in service delivery and cost minimization are managed. Internet applications require a strong server that is efficient at all times. It is evident that the cost of maintaining the system is high as a result of the international standards. Ochieng (2015) noted that Kenya Airways has long struggled with margins, but the current phase in the international business environment coupled with evolving technology and customer preferences, increased competition and diminishing margins. The communication network will help in the organization-customer communication, interdepartmental communications, and organizational-supplier communication making the services efficient; it reduces conflict between parties. the study also recommends the management to set up budgets that can sustain the ICT developments in the organization as it keeps evolving with time. For the organization to remain as a bench marks and survive in the highly competitive market technological investment has to be done.

\section{ACKNOWLEDGEMENTS}

I owe great thanks to God who have given me the power to believe in myself and pursue my dreams. I could never have done this without the faith I have in you, the Almighty. I sincerely acknowledge my lecturer and supervisor Dr. Assumptah Kagiri for her sustained enthusiasm, motivation, exemplary guidance and time he created to go through my documents with attention and care.Special thanks to my family for always understanding and having patience with me; for support and motivation in all my efforts throughout the research study.

\section{REFERENCES}

[1]. Kamau, M. (2015). Factors Affecting Strategic Choices in Airlines in Kenya: A Case Study of Kenya Airways.

[2]. Kariuki, A. (2015). Impact of Information Technology on Organizational Performance: Case of Population Services Kenya.

[3]. Ochieng , P. (2015). External Environmental Factors Influencing Financial Performance of Kenya Airways.

[4]. Wanguku, I., (2012). The Effect of Electronic Commerce on the Financial Performance of Airlines in Kenya. A Case Study of Kenya Airways.

[5]. Copeland, D., \& McKenney, J. (2010). Airline Reservations Systems: Lessons From History. MIS Quarterly, 12(3), 353-370. 
[6]. Fogli, D., Parasiliti, L., \& Bernareggi, C. (2014). A universal design resource for rich Internet applications based on design patterns. Universal Access In The Information Society, 13(2), 205-226.

[7]. Verlinda, J. A. \& Lane, L. (2013). The Effect of the Internet on Pricing in the Airline Industry.

[8]. Coombs, W. (2013). Strategic Communication in Crisis Management: Lessons from the Airline Industry. Journal of Contingencies \& Crisis Management, 11(3), 144-145.

[9]. Cooper, R. (2016). Communication and Cooperation among Competitors: The Case of the Airline Industry. Antitrust Law Journal, 61(2), 549.

[10]. Kothari, C.R. (2009). Research Methodology: Methods and Techniques,( 2nd ed.). New Delhi:New Age International Publishers. 